\title{
Evaluation Dutch preliminary nZEB requirements for hospital and university buildings
}

\author{
Wim Maassen ${ }^{1,2^{*}}$ \\ ${ }^{1}$ Royal HaskoningDHV \\ ${ }^{2}$ Eindhoven University of Technology
}

\begin{abstract}
The need for (nearly) Zero Energy Buildings (nZEBs) in the Netherlands becomes increasingly important due to climate change, increasing energy prices, scarcity of fossil fuels and increasing geopolitical conflicts. In line with the EU EPBD, from 2020 new buildings, including hospital and university buildings, have to fulfil more strict energy requirements. Besides that, also the energy requirements for existing buildings will become stricter to realize an energy neutral built environment in 2050. On request of the Dutch Universities (WO) and the Dutch Academic Medical Centre's (UMC), the Netherlands Enterprise Agency (RVO) assigned Royal HaskoningDHV to study the effect of the preliminary nZEB requirements on the real estate of the sector [1]. The feasibility of the nZEB requirements has been assessed for several representative, recently designed or realized buildings. For the selected hospital and university buildings, the results show that the preliminary nZEB requirements are not yet fulfilled. The requirement that $50 \%$ of building related energy should be of a local renewable energy source seems not to be feasible for both hospital and university buildings. Based on the results and recommendations of the study, a letter to the Dutch minister of the Ministry of the Interior and Kingdom Relations was sent and included a strong request to incorporate these in the definitive nZEB requirements, which will be set at the end of 2018 .
\end{abstract}

\section{Introduction}

One year earlier than planned, the nZEB regulation will be put into practice on the first of January 2020. Dutch Minister of the Ministry of the Interior and Kingdom Relations, Mrs. Ollongren, has written in the letter that not only new requirements are being introduced, but also the calculation method is about to be altered. The provisional nZEB requirements were already proposed in 2015 and led to many questions regarding their feasibility, in particular regarding the demand for more than $50 \%$ renewable energy generation on site. These provisional requirements from 2015 are presented in Table 1.

Table 1 Provisional nZEB definitions (2015).

\begin{tabular}{|l|c|c|c|}
\hline Building function & $\begin{array}{l}\text { Energy demand } \\
{\left[\mathrm{kWh} /\left(\mathrm{m}^{2} \cdot \mathbf{y}\right)\right]}\end{array}$ & $\begin{array}{l}\text { Energy use } \\
{\left[\mathrm{kWh} /\left(\mathrm{m}^{2} \cdot \mathbf{y}\right)\right]}\end{array}$ & $\begin{array}{c}\text { Sustainable } \\
\text { energy [\%] }\end{array}$ \\
\hline Dwellings & 25 & 25 & 50 \\
\hline Offices & 50 & 25 & 50 \\
\hline Schools & 50 & 80 & 50 \\
\hline $\begin{array}{l}\text { Health Care } \\
\text { facilities }\end{array}$ & $\mathbf{6 5}$ & $\mathbf{1 2 0}$ & $\mathbf{5 0}$ \\
\hline
\end{tabular}

The current Dutch energy performance requirements for new buildings, which have to be met until 2020, are expressed in a dimensionless number $\mathrm{E} / \mathrm{E}$, which is the quotient of the calculated and the set admissible amount of Energy use.

Among most concerned parties are university buildings and hospitals, consisting of several (often high rise) buildings. The consequences of new regulations need to be known before renovations and new constructions can be planned. Therefor the aim of this study was to discover whether current actions and practices are in line with upcoming changes in regulations in order to assure a future-proof design of healthcare facilities [1]. For this reason a number of representative buildings were selected for investigation, all being recently designed and realised projects. The methodology used in this study originates from an extended version of "Trias Energetica". This approach, used for an energy-efficient building design, has been upgraded to a 'Five-Step Method', as can be seen in Figure 1. The additional steps to the original approach are: user demand and behaviour (step 1) and energy exchange and storage systems (step 4).

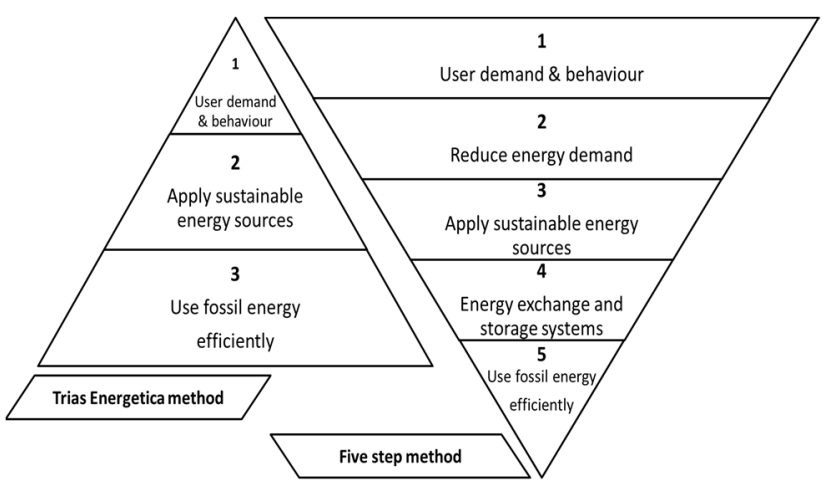

Figure 1 Building design approaches: 'Trias Energetica' versus the upgraded 'Five Step Method'.

\footnotetext{
*Wim Maassen: wim.maassen@rhdhv.com
} 


\section{Case study analysis}

The hospital building Bernhoven was selected for a more in-depth analysis. It's a 43,100 $\mathrm{m}^{2}$ facility, with around $21,600 \mathrm{~m}^{2}$ of healthcare with bed area, $16,600 \mathrm{~m}^{2}$ of area classified as "other healthcare", $3,900 \mathrm{~m}^{2}$ of office space and $1,100 \mathrm{~m}^{2}$ of gathering functions. Four different cases have been prepared, trying to comply with the required energy use $\left[120 \mathrm{kWh} /\left(\mathrm{m}^{2} . \mathrm{y}\right)\right]$, as stated in nZEB definitions for healthcare facilities see Table 1 .

Table 2 presents selected parameters of the reference scenario and changes that have been implemented in the four following cases.

Table 2. Changes introduced in Cases ZH10, ZH11, ZH13 and $\mathrm{ZH} 20$ compared to the reference case (REF).

\begin{tabular}{|c|l|}
\hline \multicolumn{2}{|c|}{ REF } \\
\hline 1 & Lighting control: room, sweep and daylight \\
\hline 2 & $\begin{array}{l}\text { Rc }=4 \mathrm{~W} / \mathrm{m} 2 . \mathrm{K} ; \mathrm{HR}++ \text {; Shades; Infil 0,6 I/(s.m2); } \\
\text { Heat recovery 70\%; lighting 9 W/m2 }\end{array}$ \\
\hline 3 & \\
\hline 4 & \\
\hline 5 & $\begin{array}{l}\text { Cogeneration of Heat and Power; Boiler; } \\
\text { Absorption Chiller; Chiller }\end{array}$ \\
\hline
\end{tabular}

\begin{tabular}{|l|l|}
\hline \multicolumn{2}{|c|}{ Changes in ZH10 $\leftrightarrow$ REF } \\
\hline 1 & $\begin{array}{l}\text { Lighting control: detection in area no beds } \\
\text { Ventilation: CO2 control }\end{array}$ \\
\hline 2 & $\begin{array}{l}\text { Rc }=9 \mathrm{~W} / \mathrm{m} 2 . K ; \text { Tripe gl; Infil 0,2 I/(s.m2); Heat } \\
\text { recovery } 90 \% ; \text { lighting } 9 \mathrm{~W} / \mathrm{m} 2 ; \mathrm{HTC} \& \text { LTH }\end{array}$ \\
\hline 3 & PV-50\% Roof: 4750 m2 \\
\hline 4 & Acquifer Thermal Energy Storage \\
\hline 5 & Electrical Heat Pump \\
\hline
\end{tabular}

\begin{tabular}{|l|l|}
\hline \multicolumn{2}{|c|}{ Changes in ZH11 $\leftrightarrow$ ZH10 } \\
\hline 1 & \\
\hline 2 & lighting 8 W/m2; Shower Heat Recovery \\
\hline 3 & \\
\hline 4 & \\
\hline 5 & \\
\hline
\end{tabular}

\begin{tabular}{|l|l|}
\hline \multicolumn{2}{|c|}{ Changes in $\mathrm{ZH} 13 \leftrightarrow \mathrm{ZH11}$} \\
\hline 1 & \\
\hline 2 & Roof-Rc=12 W/m2.K \\
\hline 3 & \\
\hline 4 & \\
\hline 5 & \\
\hline
\end{tabular}

\begin{tabular}{|c|c|}
\hline \multicolumn{2}{|c|}{ Changes in $\mathrm{ZH2O} \leftrightarrow \mathrm{ZH13}$} \\
\hline 1 & \\
\hline 2 & Roof-Rc $=10 \mathrm{~W} / \mathrm{m} 2 . \mathrm{K}$ \\
\hline 3 & \\
\hline 4 & \\
\hline 5 & District Heating (efficiency 1.5 ); Chiller \\
\hline
\end{tabular}

Various changes have been introduced to reduce the energy consumption. These four cases (ZH10, ZH11,
ZH13 and ZH20) are presented on Figure 2, together with a reference case of a current situation (REF).

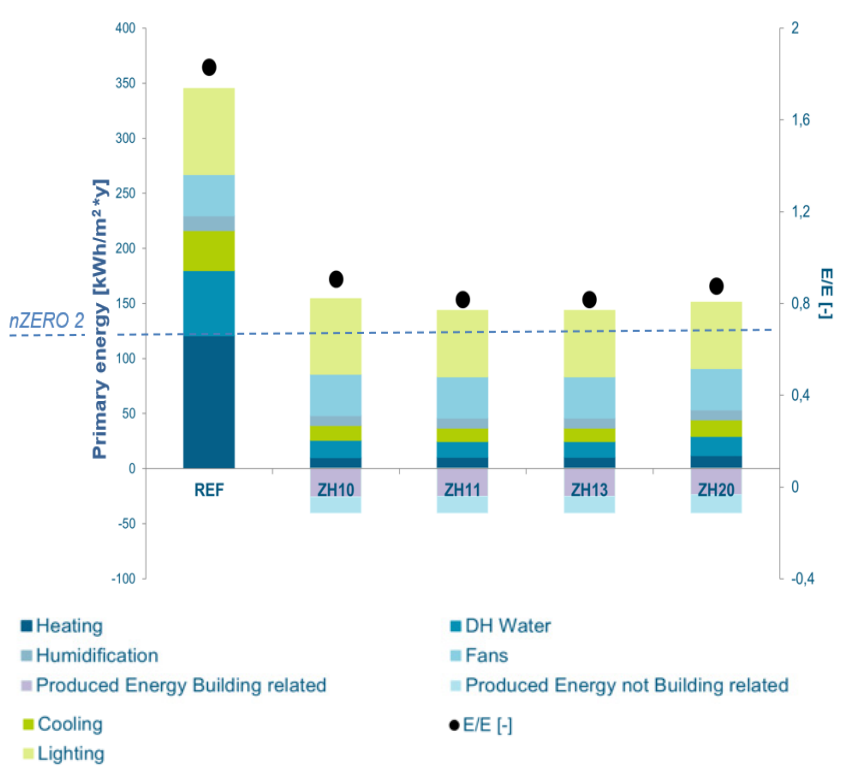

Figure 2 Results of the analysis of four cases, aiming to reduce the energy usage and comply with nZEB regulations.

The results are summarised in Table 3.

Table 3 Summarized results of the case study for a hospital in Bernhoven.

\begin{tabular}{|c|c|c|c|c|}
\hline Variant & $\begin{array}{l}\text { Energy demand } \\
{\left[k W h /\left(m^{2} \cdot y\right)\right]}\end{array}$ & \begin{tabular}{|l|} 
Energy use \\
{$\left[k W h /\left(m^{2} \cdot y\right)\right]$}
\end{tabular} & $\begin{array}{l}\text { Sustainable } \\
\text { energy [\%] }\end{array}$ & \begin{tabular}{|l}
$E / E$ \\
{$[-]$}
\end{tabular} \\
\hline Requirement & $<65$ & $<120$ & $>50$ & $<1.00$ \\
\hline Ref & $\underline{95}$ & $\underline{210}$ & $\underline{0}$ & $\underline{1.83}$ \\
\hline ZH10 & 60 & 115 & $\underline{19}$ & 0.91 \\
\hline ZH11 & 55 & 105 & $\underline{21}$ & 0.82 \\
\hline $\mathrm{ZH13}$ & 55 & 105 & $\underline{21}$ & 0.82 \\
\hline $\mathrm{ZH} 2 \mathrm{O}$ & 55 & 110 & $\underline{12}$ & 0.88 \\
\hline $\begin{array}{l}\mathrm{ZH} 20 \Rightarrow \text { B BIO } \\
\text { Heat }\end{array}$ & 55 & 83 & $\underline{39}$ & 0.66 \\
\hline
\end{tabular}

The requirement for the energy demand and energy use has been reached when the aquifer thermal energy storage system (ATES) is used instead of a combined heat and power (CHP) plant. However, the third part concerning the percentage of sustainable energy hasn't been achieved for any of the cases, even if energy generation from BIOmass was included. Hospitals have a relatively high energy consumption per square meter and often consist of several floors. In many cases, even if the roof and facade are fully covered with PV panels, the share of sustainable energy generation cannot be achieved. What makes it even harder is the fact that the cold stored in ATES, under the current EU definition, does not count as renewable energy. In the Netherlands, this system is frequently used and considered as a renewable energy source, see for example BREEAM credit ENE 5.

To reach the nZEB requirements more renewable energy has to be generated on site using additional PV, windmills, bio-mass and/or geothermal energy. However this will depend on the possibilities at the buildings 
location. Therefore the generation of renewable energy at larger distances, for example above $10 \mathrm{~km}$, should be taking into account as a solution.

Next the analysis has been conducted for 5 more hospital buildings and 4 more university buildings, see Figure 3.
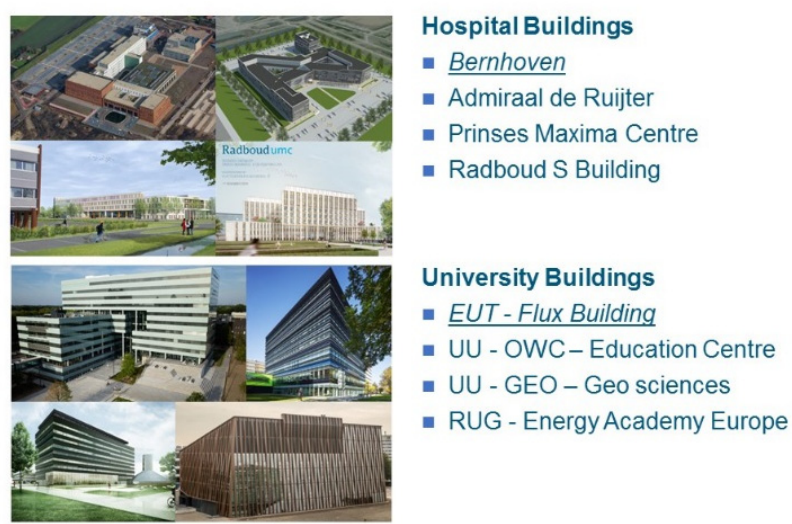

Figure 3 The hospital and university buildings which have been considered in this study.

The results are shown in Table 4 and 5.

Table 4 Summarized results of the case study for selected hospital buildings.

\begin{tabular}{|l|c|c|c|}
\hline Variant & $\begin{array}{l}\text { Energy demand } \\
{\left[\mathrm{kWh} /\left(\mathrm{m}^{2} \cdot \mathrm{y}\right)\right]}\end{array}$ & $\begin{array}{l}\text { Energy use } \\
{\left[\mathrm{kWh} /\left(\mathrm{m}^{2} \cdot \mathrm{y}\right)\right]}\end{array}$ & $\begin{array}{c}\text { Sustainable } \\
\text { energy [\%] }\end{array}$ \\
\hline Requirement & $\mathbf{6 5}$ & $\mathbf{1 2 0}$ & $\mathbf{5 0}$ \\
\hline Ref Gebouw XL 18.2 & 63 & 75 & $\underline{\mathbf{3 1}}$ \\
\hline Bernhoven & $\underline{95}$ & $\underline{210}$ & $\underline{0}$ \\
\hline Admiraal de Ruijter & $\underline{80}$ & $\underline{150}$ & $\underline{\underline{19}}$ \\
\hline Princes Maxima Center & 50 & $\underline{127}$ & $\underline{16}$ \\
\hline Radboud S-Building & $\underline{67}$ & 89 & $\underline{\mathbf{2 4}}$ \\
\hline
\end{tabular}

Again, no building apart from the reference one managed to comply to all the nZEB requirements. Mostly, none of the three requirements were met. The requirement for energy use was the highest when healthcare with bed is a dominating function.

Table 5 Summarized results of the case study for selected university buildings.

\begin{tabular}{|l|c|c|c|}
\hline Variant & $\begin{array}{l}\text { Energy } \\
\text { demand } \\
{\left[\mathrm{kWh} /\left(\mathrm{m}^{2} \cdot \mathrm{y}\right)\right]}\end{array}$ & $\begin{array}{l}\text { Energy use } \\
{\left[\mathrm{kWh} /\left(\mathrm{m}^{2} \cdot \mathrm{y}\right)\right]}\end{array}$ & $\begin{array}{l}\text { Sustainable } \\
\text { energy [\%] }\end{array}$ \\
\hline Requirement & $\mathbf{5 0}$ & 60 & 50 \\
\hline EUT - Flux Building & $\underline{65}$ & $\underline{104}$ & $\underline{18}$ \\
\hline UU - Education Centre & $\underline{\mathbf{7 4}}$ & $\underline{\underline{127}}$ & $\underline{\mathbf{2 7}}$ \\
\hline UU - Geo sciences & 41 & $\underline{\underline{91}}$ & $\underline{10}$ \\
\hline RUG - Energy Academy Europe & 29 & $\underline{-11}$ & 132 \\
\hline
\end{tabular}

The results for 4 university buildings were similar as the results of the hospital buildings although less measures are required to meet the energy demand and energy use requirements. However again the third requirement, regarding sustainable energy, was hard to meet.

\section{Discussion}

The points of attention are, among others, the limited number of building definitions. The assessment can improve by creating better definitions for more building functions and sizes. Especially hospitals should get more attention on the layout of building functions based on ventilation demands seen in practice.

The requirements regarding the amount of ventilation for each room in a hospital differ strongly. Another point of attention is considering the cold of the ATES as renewable energy. Also, more realistic assumptions internal heat gains and the use of hot water in the calculation method should be adapted to give more realistic values.

The value for sustainable energy share should be lowered and made more flexible, depending on the location of the building and the availability of renewable energy sources. If there is no possibility to apply a thermal storage system, other techniques should be considered, such as geothermal energy, all-electric smart grids, biomass/gas in combination with other smart solutions that could help reach the energy requirements.

\section{Conclusions}

The main conclusion of the study is that the provisional nZEB requirements are not met by any of the considered case studies and the requirement on sustainable energy is so strict that it really is very hard to comply with. Therefor the nZEB requirements should be reconsidered.

\section{Recommendations}

The study resulted in the following list of recommendations:

1) Increase the number of building types for which separate nZEB definitions are set and provide clarity on the typology of the building for evaluating compliance with the nZEB requirements.

2) Consider the cold stored in Aquifer Thermal Storage System as renewable energy.

3) Research/optimize starting points for different building functions, particularly for health care facilities such as hospitals. Certain fixed numbers are very high or unrealistic compared to practice.

4) Create a new subdivision in building functions to be considered in hospitals, based on ventilation requirements.

5) Check whether the nZEB requirements, depending on the location and possibilities, can be implemented in steps. (Example: new construction which is coupled to the existing energy infrastructure on campus)

6) Reduce nZEB-3 requirement (Sustainable Energy) for higher education and hospitals. The current $50 \%$ is not feasible on site. Proposal: $20 \%$ of hospitals and $30 \%$ for 
higher education. Or: Allow the possibility to generate energy beyond the $10 \mathrm{~km}$ limit.

7) The nZEB-1requirement concerning the energy demand is the most important requirement. Buildings have a lifespan of around 40-60 years, meaning that a good design can provide significant energy savings and reduction in $\mathrm{CO}_{2}$ emissions during all that time. Research ways to reduce the energy demand and substitute the other two parameters of the regulation with only this one (example: nZEB Hospital Building research project that Royal HaskoningDHV carried out in cooperation with the TU/e [2] and [3]).

8) Collect more practical information, which the standard can be based on. Also provide reliable and proven solutions.

9) Determine financial feasibility based on the EU cost optimality.

10) The Dutch Government should keep the building owners and other stakeholders updated on the development of the final nZEB requirements. At the moment the Dutch government is developing simultaneously a new Energy calculation method, based on CEN standards, and setting the definitive nZEB requirements. On November $20^{\text {th }} 2018$ a new version of nZEB regulations was published and the requirements which have to be calculated with the new calculation method are shown in Table 6 below.

Table 6 Updated nZEB requirements from November 2018.

\begin{tabular}{|l|c|c|c|}
\hline Building function & $\begin{array}{l}\text { Energy demand* } \\
{\left[\mathrm{kWh} /\left(\mathrm{m}^{2} \cdot \mathrm{y}\right)\right]}\end{array}$ & $\begin{array}{l}\text { Energy use } \\
{\left[\mathrm{kWh} /\left(\mathrm{m}^{2} \cdot \mathrm{y}\right)\right]}\end{array}$ & $\begin{array}{l}\text { Sustainable } \\
\text { energy [\%] }\end{array}$ \\
\hline Offices & $90+$ curve & 50 & 30 \\
\hline Schools & 180 & 80 & 40 \\
\hline $\begin{array}{l}\text { Health Care } \\
\text { facilities - no bed }\end{array}$ & $100+$ curve & 60 & 40 \\
\hline $\begin{array}{l}\text { Health Care } \\
\text { facilities - with bed }\end{array}$ & $\mathbf{3 5 0}$ & $\mathbf{1 5 0}$ & $\mathbf{3 0}$ \\
\hline
\end{tabular}

The Netherlands Enterprise Agency (RVO) assigned Royal HaskoningDHV to study the effect of the these new nZEB requirements on the real hospital and university buildings considered in this sturdy. The results will be available in February 2019.

\section{References}

[1] Maassen, W.H., Peeters, B., RAPPORT - BENG eisen en Utiliteitsgebouwen voor Hoger Onderwijs en Universitair Medische Centra/Ziekenhuizen, Studie naar haalbaarheid BENG eisen, Reference: I\&BBF1511R001D1.2, Date: October $27^{\text {th }} 2017$

[2] Maassen, W.H., REPORT (nearly) Zero Energy Hospital Buildings, Reference:

I\&BBE3112R001F0.1, Revision: 0.1/Final, Date: 25 January 2017, [Online]. Available:

https://tc0906.ashraetcs.org/I\&BBE3112R001D0 1\%20nZEB $\% 20$ Hospital $\% 20$ Buildings $\% 2017011$ 25.pdf
[3] REHVA Journal 2017/05, HVAC in Health Sector, NZEB Hospitals case studies, October 2017, [Online]. Available:

https://www.rehva.eu/fileadmin/REHVA Journal /REHVA_Journal_2017/RJ5/RJ1705_WEB.pdf

\section{Appendix}

More detailed information about cases is given in the Table below.

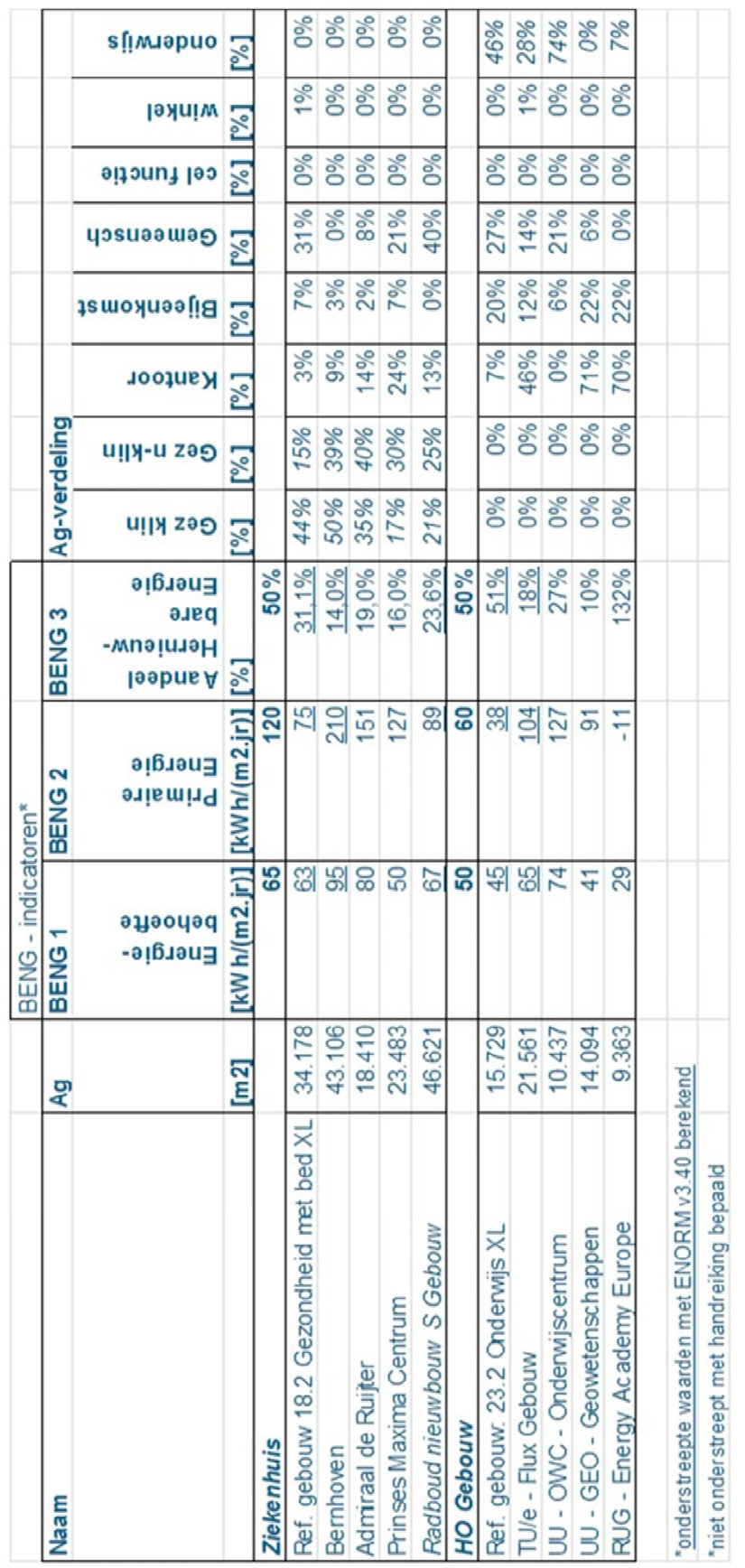

